\title{
On Life Sentences
}

S.A.

Thank you for giving us this forum to express our many well-founded grievances with this terrible system we are suffering under. I do very much hope that the people who can help change this broken system have a chance to hear what we have to say. I have been incarcerated for more than 15 years and have seen nosedive in the Canadian justice system and in the Correctional Service of Canada (CSC). We seem to be moving away from what Canada is supposed to stand for and have become something very cruel, even somewhat evil. I understand that people who make certain mistakes have to pay and must learn from them so that they do not fall back into a negative cycle, but what is truly going on behind prison doors is a terrible injustice and stain on what we feel Canada should be. People should really take a closer look at what right-wing politics have done to our country (see Cook and Roesch, 2012). It is noticeable to me, because I am at the closest level to the very bottom of our society. From my view looking up, I can see and understand things that most people who are not in my position cannot even dream of. As a society we must look at the very bottom, the very foundation of our society, and what we believe that our country stands for so that we can truly understand our shortcomings. It is like they say a chain is only as strong as its weakest link. Our society is only as strong as the weakest link, the very bottom of the bottom. That saying is so powerful, and so honest, that it should be the founding creed of any fair, progressive, moral, honest, socially advanced country. It should be the measuring stick that Canadians judge their society by.

It is easy to say that our system is better than many countries and it is, to some extent, true. Here in Canada we say we have a non-vigilante system of rehabilitation, but every chance and option that a convict tries to use to better themselves and to truly rehabilitate is blocked by the very system that is there to 'help'. How can Canada say we are rehabilitating our people when we hand out lengthy life sentences? How can people rehabilitate under any life sentence! We cannot claim to be better than other countries because of their lack of human rights when we ourselves lack the needed compassion to support our prisoners' rights, thus improving our country and society as a whole. We must build from the very bottom if what we are building is to be true. 


\section{WHAT IS TO BE DONE?}

- We as a society must end life sentences.

- We must provide more job training, computer education, and more schooling (technical and professional), so that we can give prisoners the tools they need to rehabilitate and remain 'crime' free.

- We must end all harsh sentencing laws.

- We must pay our prisoners a much better pay than we are paying them today.

We must take these issues seriously and act quickly because our society is being damaged and needs to be fixed. Our foundation has a cancer and it is spreading and eventually this rot will touch the penthouses. We may not need to lead "the best country in the world list", but we should not be comparing ourselves to the world's worst.

\section{REFERENCES}

Cook, Alana and Ronald Roesch (2012) “'Tough on Crime' Reforms: What Psychology Has to Say About the Recent and Proposed Justice Policy in Canada", Canadian Psychology, 53(3): 217-225.

Fournier-Ruggles, L. (2011) “The Cost of Getting Tough on Crime: Isn't Prevention the Policy Answer?", Journal of Public Policy, Administration and Law, 2(1): 19-27.

\section{ABOUT THE AUTHOR}

S.A. is imprisoned at Archambault Institution. 